\title{
FUNKCINĖS MUTACIJOS FENOMENAS IR JO İTAKOS ISTORINEI KAUNO IR KLAIPĖDOS MIESTŲ APLINKAI
}

\author{
Skirmantė Mozūriūnaitė \\ Urbanistikos katedra, Vilniaus Gedimino technikos universitetas, \\ Pylimo g. 26/Trakug. 1, 01332 Vilnius, Lietuva \\ El.paštassmozuriunaite@gmail.com
}

Iteikta 2011-11-22

\begin{abstract}
Santrauka. Miestai yra kompleksiška ir daugiafunkcė sistema, kuri nuolatos vystosi, keičiasi ir adaptuojasi, kad išliktų. Straipsnyje aptariamas Lietuvos miestų pavyzdžiu atlikto empirinio tyrimo funkcinių mutacijų reiškinys ir jo pasekmès miestų istorinių dalių kaitai. Detaliai tiriant socialinių, ekonominių, fizinių, globalinių ir technologinių procesų poveikị nustatyta Kauno ir Klaipédos miestų istorinių gatvių funkcijų kaita ir aplinkos transformacijų (mutacijų) mastas bei priežastys. Aptariamos urbanistinių funkcijų kaitos pasekmès miesto istorinei aplinkai, architektūriniam identitetui ir proceso dèsningumui. Straipsnyje pateikiama atliktų tyrimų metodika, proceso dèsningumai. Šio straipsnio tikslas - atskleisti miesto funkcijų mutacijas lemiančius veiksnius ir jų pasekmes.
\end{abstract}

Reikšminiai žodžiai: mutacijos, veiksniai, transformacijos, funkcijų nykimas ir mutacija, sklaida, urbanistinès funkcijos, funkcinès mutacijos.

\section{Ivadas}

Šiame straipsnyje nagrinejjamas savaiminių mutacijų atsiradimas, jų tipai ir samprata, urbanistinių funkcijų kaitą lemiantys veiksniai ir jų tyrimo klausimai jau yra aptarti pristatant Vilniaus istoriniame centre vykstančiu procesų tyrimą (Mozūriūnaitė 2010). Čia toliau nagrinejjamos plètros ir planavimo sistemos sukurtos problemos, kurių pasekmès nepastebimos ir dažnai yra vertinamos kaip naujos problemos. Atlikti Kauno ir Klaipedos miestų funkcijų sklaidos istorinëje miesto dalyje tyrimai patvirtino mutaciju proceso, kaip savaime besivystančio (self-organised) reiškinio, ir jas nulèmusių veiksnių visumą. Straipsnyje vartojami tarptautinëje mokslinejje literatūroje taikomi terminai. Straipsnio tikslas yra pristatyti urbanistinių funkcijų sklaidos Kauno ir Klaipèdos centrinèse dalyse tyrimo rezultatus.

\section{Funkcijų istorinëje aplinkoje tyrimo metodika}

Natūrinis tyrimas atliktas Kauno ir Klaipedos miestų istorinès dalies branduolyje. Tyrimui atlikti buvo naudojami empiriniai, analizès (istoriniai, atkuriamieji, statistiniai ir kt.) metodai. Didžioji darbo dalis paremta kiekybinio funkcijų tyrimo duomenų analize, nustatant jų dėsningumus. Duomenys sukaupti atliekant natūrinị tyrimą, nagrinejjant istorinius, literatūros, kartografinius, statistinius šaltinius.

Darbo rezultatų duomenų analizè atlikta naudojant daugiasluoksnę medžiagą: žemèlapius, telefonų abonentų knygas, statistines duomenų bazes, daktaro disertacijas, istorinę literatūrą ir kt. Funkcinès struktūros tyrimas atliktas naudojant lyginamosios analizès metodą. Atsižvelgus ị tiriamo objekto sudètingumą, visapusiškam jo atskleidimui naudota trianguliacija, derinant mokslinès literatūros ir dokumentų analizę, taikant rekonstrukcijos metodą. Atliktas kiekybinis tyrimo rezultatų apdorojimas suteikè galimybę identifikuoti esminius funkcinių mutacijų atsiradimo momentus, jų kaitą ir slinktis.

\section{Mutacijas lemiantys veiksniai}

Šių dienų miestai, ypač centrinès jų dalys, per pastaruosius dešimtmečius smarkiai keitèsi ir keičiasi toliau. Todèl funkcinès mutacijos tyrimas buvo atliekamas klasikinio miesto - jo istorinès dalies centriniu gatvių - branduolyje, kuris, formuojamas socialinių, ekonominių ir kitų veiksnių, puikiai atspindi istori- 
nius ir dinaminius miesto raidos etapus. Istoriškai susiklostęs gatvių tinklas, didelè funkcijų ịvairove ir gyventojų tankis bei saugoma urbanistinè struktūra leidžia nustatyti ir identifikuoti funkcijų kaitos, jos slinkties ir mutacijų momentus.

Pastebima, kad centrinès miestų dalys priklausomai nuo jose vyraujančių funkcijų (paslaugų, komercinès, kultūrinès, rekreacinès ir t. t.), taip pat struktūros ir lokacijos mieste vis dažniau patiria panašius pokyčius. Vis sunkiau atskirti ir identifikuoti grynąsias funkcijas, kurios nekito, nebuvo transformuotos, nes sparčiai keičiantis gyvenimo būdui, technologijoms ir kultūrai, naujosios transformuotos ir mutavusios funkcijos keičia senąsias, kurios yra kompleksiškos, daugialypès, lanksčios ir sugeba prisitaikyti (Mitchell 2002). Naujų funkcijų kūrimasis ir sparti miestų kaita tiesiogiai priklauso nuo laiko, erdvès, miesto urbanistinės struktūros bei kitų miesto plètros sąlygų: ryšių, gyventojų tankumo ir jų pasiskirstymo mieste. Todèl šias funkcijas galima būtų suskirstyti ị skatinančias funkcinius ir fizinius veiksnius. Priklausomai nuo miesto teritorijos (maža „S“, vidutinè „M“, didelè „L“) vyrauja veiksnių sluoksnių ịvairovè ir vertikali jų tarpusavio sąveika per tam tikrą laiką (1 pav.). Remiantis atliktais natūriniais tyrimais, mokslinės literatūros studijomis, galima teigti, kad urbanistinių funkcijų kaitą ir mutacijas inicijuoja (skatina) skirtingi veiksniai.

Ekonominiai veiksniai. Vykstant pramonès revoliucijai formavosi santykiai tarp žmonių ir mašinų, tačiau dabartinis globalus skaitmeninių komunikacijų periodas nustato naujus žmonių ir informacijos, informacinių technologijų santykius, kurie tampa plètros raktu, leidžiančiu sukurti naujas socialines struktūras ir urbanistinius modelius (William 2002). Vienas iš pagrindinių ir žymiausių ekonominių veiksnių yra suinteresuotų asmenų ar politinių interesų grupès, darančios įtaką tolesnès miesto raidos kryptims.

Tuo pat metu pasaulio ekonomiką veikia tarptautinès finansinès ir gamybinès sistemos, sunkiai kontroliuojamos nacionalinių vyriausybių ir nuošalyje paliekančios miesto valdžios atstovus. Kuriant naujas darbo vietas ir naujas paslaugas, naudojant skaitmenines technologijas, gamyboje dirbančių žmonių skaičius sparčiai mažèja. Daugejja darbo vietų paslaugu sektoriuje, įmonès išlieka susijungdamos su giminingą veiklą vykdančiomis įmonèmis, didindamos savo pranašumą, arba nyksta. Šis įmonių susijungimo reiškinys pastebètas Marshall (1989). Toks funkcijų grupavimasis ir koncentravimasis grindžiamas keliomis esminèmis priežastimis:

- funkcijų aglomeracija, kuri suteikia platų darbuotojų, turinčiu specializuotas kompetencijas, pasirinkimą;

- specializuotų funkcijų (produktų ar paslaugų) vystymo palengvinimu;

- funkcijų tarpusavio sąveika, kai įmonès naudojasi viena kitos žiniomis (Jucevičius 2007).

Šiuolaikinę ekonomiką galima vadinti globalia ekonomika, nes svarbiausios veiklos rūšys mityba, vartojimas, platinimas ir jų sudedamosios dalys - tiesiogiai susijusios su ekonomikos subjektu ir organizuojamos globaliai. Šis svarbus globalios ekonomikos veiksnys ne tik Europoje, bet ir Lietuvos miestuose inicijuoja funkcijų mutacijas, skatina investicijas ir keičia žmonių užimtumą. Naujosios, transformuotos funkcijos tampa pranašesnès, turèdamos polifunkcinių savybių ir sugebančios lengviau adaptuotis kintančioje rinkos ekonomikoje. Globalinès ekonomikos privalumai bei pranašumas yra neatsiejami nuo finansinių ir ekonominių rinkos svyravimu - krizių. Šių krizių vienas iš pagrindinių indikatorių miestuose yra funkcijos. Kiekvienos šalies atveju galima išskirti skirtingus ekonomikos modelius, kurių kiekvienas bus grịstas šalies socialine, finansine sistema, gamyba ir t. t. Kiekviena iš jų turi grèsmių, bet mažesni protų nutekèjimo (angl. brain drain) (Korcelli-Olejniczak 2007) pavojų patiria aukštosiomis technologijomis grịsta ekonomika. Ekonominiai veiksniai yra tiesiogiai susiję su miestų funkcijomis pagrindiniu jų indikatoriumi.
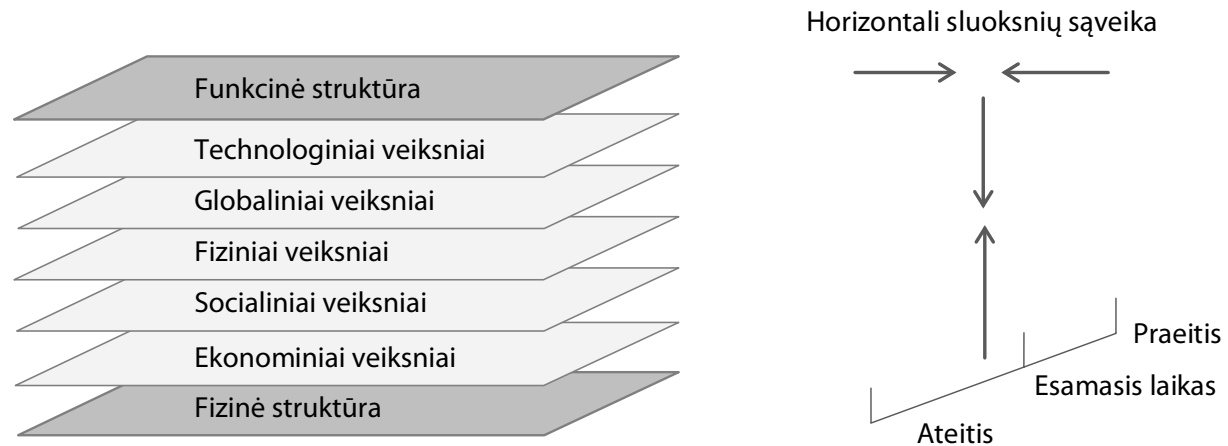

1 pav. Mutacijas skatinantys veiksniai (pagal Geyer (2001) „a human activities" modelį)

Fig. 1. Mutation promoting factors (according to the Human Activities Model by Geyer (2001)) 
Socialiniai veiksniai. Kuriant ekonominius miestų egzistavimo pamatus pasikeitė miestiečių gyvenimo būdas, požiūris ị daiktus ir gyvenimą (Rogers et al. 2000). Socialinè atskirtis neišnyko, tačiau ji pasireiškè „skeldejimu“ pagal socialinius požymius. Ją didina funkcinè miesto dezintegracija, miesto ekspansija i priemiesčius, kaimo vietoves (Juškevičius 2007). Ypač akivaizdus socialinès segregacijos reiškinys, sukeltas nekilnojamo turto ir žemès kainu. Esant socialinei segregacijai, kuriasi uždaros bendruomenès, kurios sujungia tik tam tikrų pajamų ir tam tikro socialinio sluoksnio atstovus. Šios bendruomenès užsienio literatūroje dažnai vadinamos „uždaromis bendruomenèmis" (angl. gated comunities). Tokių uždarų bendruomenių pavyzdžių sutinkama ir Lietuvos miestuose. Socialinès segregacijos didina grèsmę apleistoms, nepatrauklioms miesto gyvenamosioms teritorijoms, iš kurių išsikelia turtingesni gyventojai. Socialinè įvairovè gyvenamuosius kompleksus padalina į atskirus polius-getus, uždaras bendruomenes, taip keliama grèsmè visuomenei. Todèl skirtingose šalyse vykdant skirtingas planavimo strategijas, prabangius kvartalus bandoma integruoti i žemesnio socialinio lygmens struktūras. Tačiau Lietuvoje šio reiškinio „darniųjų salų" modelio taikymas neaptiktas.

Socialinių veiksnių kaitą taip pat lemia technologiniai pasikeitimai, kurie skatina esminius moterų, vyrų ir vaiku santykius bei asmenybès, seksualumo sampratos pokyčius (Castells 2005). Pagrindinè šeimos modelio kaita - gyventojų ir darbo rinkos pokyčiai lèmé namų ūkio pertvarką ir šeimos dydị. Nuo 20 a. penkių asmenų šeimos sudètis sumažèjo iki dviejų narių šeimoje. Šis šeimos modelio mažèjimas turi daug priežasčių, tačiau vienos iš pagrindinių yra šios (Rogers et al.2000):

- vis ilgiau gyvena vyresnio amžiaus žmonès, kurie turi atskirus būstus;

- vedybos ir vaikai planuojami vis vèlesniame amžiuje;

- šeimose susilaukiama mažiau vaikų;

- dramatiškai didèja skyrybų ir vienišų tèvų skaičius;

- didejja moterų emancipacija ir ekonominè nepriklausomybè.

Gyventojų struktūra kinta, jauniausiųjų gyventojų banga, negalinti ịpirkti gyvenamojo būsto gyvenamuosiuose kompleksuose arti istorinio branduolio, slenka kartu su naujų gyvenamųjų kompleksų statyba, dèl to gyventojų struktūra juose „svyruoja“. Susiformavus naujiems šeimos modeliams ir jos sudéčiai, formuojasi naujas gyvenamujų kompleksų poreikis. Demografinio gyventoju pasiskirstymo mieste kaita atsiranda dèl koncentruotos ir slenkančios daugiabučiu gyvenamuju kompleksų plètros (Jucevičius 2007).
Šiame nekontroliuojamų pokyčiu pasaulyje žmonès ima grupuotis pagal pamatinių tapatumų kategorijas religiniu, etniniu ar socialiniu pagrindu. Naujo tipo bendruomenès formuojasi ne tik pagal išvardintas tapatumo kategorijas, bet ir pagal pažangių technologiju vartojimo požymį, kai senąsias miesto erdves keičia elektroninè (skaitmeninè) erdvè, telkdama žmones, turinčius bendras vertybes ir interesus, komunikuoti virtualioje erdvejje. Socialiniu erdviu isigalejimas yra siejamas su metropolizacija, kuri skatina išcentrinius gyventojų sklaidos procesus ir erdvinị bei socialinị atskirtumą.

Fiziniai veiksniai. Šiam veiksniui tikslinga priskirti laiko, erdvès, klimato, infrastruktūros ir ryšių kaitą. Užuot buvęs tvarkingas, patrauklus ir geras, suplanuotas mūsų miestovaizdis tampa savaiminių deformacijų ir apgriuvusių gatvių aplinka. Apleistos senesnès teritorijos, buvusios pramoninès įmonès ir gamyklos, virtusios miesto vaiduokliais, dažnai netikusiai įtrauktos į miesto struktūrą arba, prijungtos prie jo pakraščių, tampa bendros miesto plètros dalimi (Rogers et al. 2000). Klimato kaitos pokyčiai pastebimi ne tik gamtoje, bet ir miestuose. Keičiantis oro temperatūrai, keičiasi ir miesto gyvenimo ritmas ir ịpročiai. Atšilus klimatui, aktyviau pradètos naudoti viešosios erdvès, formuojasi nauja lauko (atvirų) erdvių kultūra. Šalto klimato šalyse formuojasi naujos funkcijos uždarose patalpose. Miesto erdvių ir skirtingo charakterio gatvių naudojimą keičia ne tik klimatiniai, bet socialiniai ir ekonominiai veiksniai bei ryšiai (viešojo transporto ir pèsčiųjų srautai).

Erdvę ir laiką transformuoja informacinių technologijų paradigmos bei dabartinių istorinès kaitos nulemtų socialinių formų ir procesų poveikis (Castells 2005). Spartejjantis gyvenimo ritmas ir 24/7 (dvidešimt keturias valandas per parą, septynias dienas per savaitę) gyvenimo kultūra sukuria aktyvų ir nenutrūkstamą miesto erdvių naudojimą. Toks gyvenimo būdas išpopuliarèjo atsiradus prekybos centrams, kurie suteikia visas reikalingiausias paslaugas. Tačiau vis dažniau technologijų spartos sąveika erdves keičia skaitmeninèmis erdvèmis, kurios naudojamos ne tik socialiniam bendravimui, bet taip pat ekonominei, kultūrinei ir kitoms veikloms. Naujoji komunikacijos sistema radikaliai transformuoja erdvę ir laiką - pamatines žmogaus gyvenimo plotmes. Atsiradusi internetinè prekyba, virtualios meno galerijos, kinas, nuotolinès internetinès paskaitos, konferencijos ir kt. praranda laiko matą (atskaitą). Laikas tampa bematis (angl. timeless), vietovès netenka savo kultūrinès, istorinès, geografinès reikšmès ir yra reintegruojamos ị funkcinius tinklus ar vaizdų koliažus: taip yra kuriama srautų erdvė, kuri išstumia viešąsias erdves. 
Naujoji komunikacijos sistema ištrina ir laiką, konstruoja ji bemateje sistemoje, nes praeitis, dabartis ir ateitis gali sąveikauti vienu metu, vienoje vietoje. Skaitmeninių, kitaip dar vadinamų virtualiųjų, srautų erdvès ir bematis laikas yra naujosios kultūros pamatai. Tai yra realiosios virtualybès kultūra, kurioje fantazija tampa tikrove (Castells 2005). Viešųjų erdvių pavyzdžiu Lietuvoje galima būtų ịvardinti vieną iš pirmųjų virtualių svetainių socialinio tinklalapio programą „mIrc“, kurią pakeité facebook vienas iš populiariausių pasaulyje socialinių tinklalapių.

Globalizacijos veiksniai. Globaliniai procesai - tai procesai, kurių negalime įvardyti „gerais“ ar „blogais“. Globalizacijos veiksnį reikètų suvokti kaip daugialypi socialinių, ekonominių procesų darinị, nesutelpantị i jokius vienos tematikos rèmus (Stenger 2008). Šis procesas veikia ne tik socialinius, ekonominius, kultūrinius veiksnius, bet ir urbanistinę miesto struktūrą. Fizineje miesto struktūroje formuojasi naujos morfologinès formos, nauji hibridai (pvz.: prekybos centrai, verslo parkai, logistikos centrai ir t. t.), kurie darko urbanistinį audinị, kvartalų morfologiją bei sutrikdo miesto funkcinių sistemų darbą pakeisdami žmonių ir gyventojų srautus. Taip pat pastebimas ne tik kultūrinis, bet ir architektūrinio miestų stiliaus supanašejimas ir asimiliacija. Globali ekonomika, didieji prekiniai ženklai sutinkami kiekviename mieste, garsiausių pasaulio architektų darbai puikuojasi didžiausiuose pasaulio miestuose, skatindami miesto identiteto susilpnejjimą ar jo praradimą. Šis reiškinys pastebimas ir didžiuosiuose Lietuvos miestuose ne tik architektūrinejje pastatų išraiškoje, miestų planavimo strategijose, bet ir tarp funkcijų ir prekinių ženklų gausos.

Technologiniai veiksniai. Sparti informacinių technologijų plètra kuria esmines prielaidas žinių visuomenei formuotis. Technologijų suklestejimo rezultatai tampa fiziniais ir socialiniais veiklos objektais (angl. artefacts). Gyvenimas ir darbas tampa lengvesni, techno- logijos sudaro svarbias sąlygas darbo pokyčiams, tačiau nèra vienintelè šių pokyčių varomoji jèga (Jucevičius 2007). Naujų technologiju privalumai sukuria naujus žmoniu mobilumo poreikius ir ịpročius, daro įtaką nusistovejusiai urbanistinès struktūros funkcionavimo sistemai. Keičiasi fizinè ir funkcinè struktūra, formuojasi naujos funkcijos ir morfotipai pagal naujus gyventojų poreikius. Gyvenimo būdo pasikeitimai ir technologiniai irankiai leidžia transformuotis ir susidaryti naujiems morfotipams (vyksta savaiminès mutacijos). Išnyksta laiko ir erdvès skirtumai, skatinantys ir didinantys darbo našumą. Šis naujas skaitmeninis sluoksnis arba lygmuo yra funkcinių mutacijų pavyzdys, atsiradęs veikiant technologinių veiksnių kaitai. Tačiau technologinè revoliucija ne tik keičia laiko ir erdvès sampratas, bet ir pradeda vis sparčiau keisti nusistovejjusius materialius visuomenès pagrindus. Formuojasi lankstūs darbo modeliai, kurie skiriami pagal požymius ir priežastis (1 lentelè).

Taigi, miestas yra priemonè, skirta žemès naudojimui organizuoti, o virtualus miestas - priemoné, skirta virtualiai erdvei organizuoti. Mes esame liudininkai, žengiantys ị naująją informacinę erą (Mumford 1953). Praejjusio amžiaus technologijas pakeite mechanizuotos, 24/7 veikiančios technologijos, gebančios protauti bei sąveikauti tarpusavyje. Skaitmeninès technologijos ir komunikacijos įsigalèjo žaibišku greičiu. Jos keičia net pamatines šimtmečius gyvavusias funkcijas, tokias kaip popierini paštą (snail mail) (Stenger 2008). Interneto sklaida ir „virtualiai aktyvios sistemos" keičia ir šalių kultūrinio paveldo aplinką, socialinę etiką ir miesto struktūros naudojimą. Technologijų nulemtą istorijos raidą bei socialinius pokyčius negalima vertinti vien teigiamai, tačiau jos išreiškia visuomenès gebejjimą transformuotis ir pasirinkti būdus, kaip panaudoti savo intelektinị potencialą.

Aptarti veiksniai, lemiantys funkcijų kaitą ir sklaidą miestuose, negali būti išskirti kaip individualūs, nes są-

1 lentelè. Darbo modelių lentelè

Table 1. Work models

\begin{tabular}{|c|c|c|}
\hline Darbo modelis pagal & Požymiai & Priežastys \\
\hline darbo laiką & $\begin{array}{l}\text { nevaržo tradicinis darbo laikas, } \\
\text { laisvas darbo grafikas }\end{array}$ & \multirow{2}{*}{$\begin{array}{l}\text { žmonių užimtumas žemès ūkyje } \\
\text { mažèja užimtumas tradicinèje pramoninèje } \\
\text { gamyboje }\end{array}$} \\
\hline darbo vietos stabilumą & $\begin{array}{l}\text { orientuotas i užduoties vykdymą, todèl } \\
\text { nereikia darbo ateityje garantijų }\end{array}$ & \\
\hline vietą & $\begin{array}{l}\text { netradicinè darbo vieta yra ne įmonèje, o } \\
\text { namie, kelyje ar kitur }\end{array}$ & \multirow{2}{*}{$\begin{array}{l}\text { verslo ir socialinių paslaugų plètra } \\
\text { auga paslaugų kaip užimtumo šaltinio įvairovè } \\
\text { biuru tarnautojų bei prekybos darbuotojų } \\
\text { lyginamojo sverto augimas }\end{array}$} \\
\hline $\begin{array}{l}\text { socialinę darbdavio ir } \\
\text { darbuotojo sutarti }\end{array}$ & $\begin{array}{l}\text { karjeros siekimas pagal iš anksto žinomus } \\
\text { reikalavimus (pašalpos, galimybès tobulinti } \\
\text { kvalifikaciją, kt.) }\end{array}$ & \\
\hline
\end{tabular}




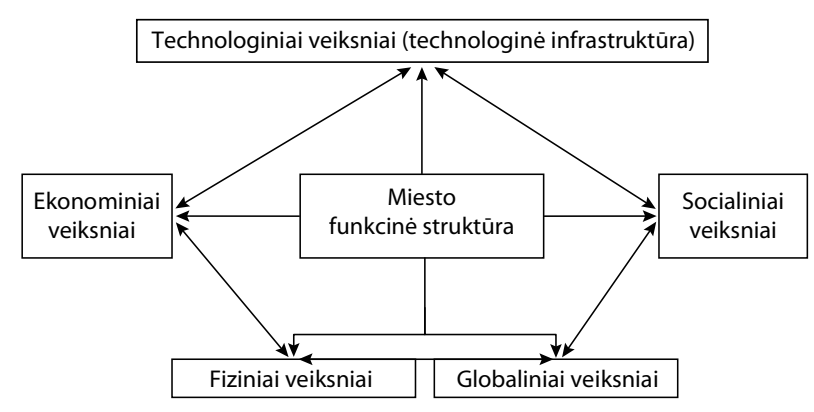

2 pav. Funkcinių veiksnių modelis

Fig. 2. Functional factor model

veika tarp veiksnių ir miesto funkcinės struktūros yra nenutrūkstanti ir uždara ( 2 pav.). Minèti pavyzdžiai patvirtina, kad protiniam darbui atlikti nereikalingas kojų darbas. Išnyksta fiziniai atstumai ir laiko barjerai. Todèl galime drąsiai teigti, kad formuojasi nauji visuomeniniai ţpročiai ir bendruomeniniai santykiai. Naujos telekomunikacijų sistemos suteikia galimybę miesto funkcines sistemas (darbovietes, transporto sistemą, gyvenamąją teritoriją) sujungti ị bendrą visumą ir kurti naują urbanistini (skaitmeninių technologijų) miesto modeli.

Visi anksčiau išvardinti veiksniai, inicijuojantys (skatinantys) mutacijas, sutinkami tiek Lietuvoje, tiek didžiuosiuose pasaulio miestuose, jie nepabrèžia miestų charakterio ir savitumo, o veda jo išnykimo link. Globalizacija ir informacinių technologijų vystymosi sparta panaikina daugelį barjerų, suaktyvina pasaulinę žmonių migraciją ir emigraciją, sukelia kultūrų asimiliaciją, supanašėjimą (Stenger 2008).

\section{Funkcijų sklaida Kauno ir Klaipèdos miestų istorinèse dalyse}

Tiriant Kauno ir Klaipeddos klasikinio miesto funkcijų kaitą išryškejja funkcinès mutacijos, kurios yra būdingos šiems skirtingiems miestams ir jų lokacijai. Lietuvos miestų dominuojančias funkcijas galima būtų grupuoti pagal ilgaamžiškumą ir lankstumą (prisitaikymą prie esamų rinkos ekonomikos ir kitų sąlygų). Šias funkcijų grupes pagal Galinie et al. (2004) galima susieti su jų mutacijų galimybėmis. Tačiau augant miestams, funkcijos asimiliuojasi, transformuojasi arba traukiasi tapdamos mišriomis. Šiems kaitos ir tipologijos metodams identifikuoti, nustatant funkcijų sklaidą ir dinamiką, nepakanka atliktos vienų metų funkcijų analizès, todèl Kauno ir Klaipedos 2010 metų tyrimui taikytas kiekybinis funkcijų kaitos tyrimo metodas. Miestų centrai buvo ir yra inovacijų generatoriai, o naujai besiformuojančios inovacijos skatina mutacijas. Nepaisant inovacijų nulemtos funkcijų slinkties, didžiausia funkcijų koncentracija išlieka centrineje miesto dalyje (Burdett 2008). Atliktais tyrimo duomenimis Kauno ir Klaipedos miestų centrinejje dalyje 2010-2011 m. matoma žmonių ir funkcijų mažejjimo (regresijos) tendencija. Tuštejjančios centrinių miestų gatvès - didžiulè problema, vis dažniau pastebima centinèse Europos didmiesčių dalyse. Dominavusią gyvenamąją funkciją ir kitas visuomeninio maitinimo, gyventojų aptarnavimo, kultūrinę ir vaikų ịstaigų funkcijas keičia vyriausybinès ịstaigos, finansinès ir teisinès veiklos funkcijos (2 lentelè).

Lenteleje pateikti duomenys iliustruoja dominuojančias Kauno ir Klaipédos istorinio branduolio funk-

2 lentelè. Funkcijų sklaida Kauno ir Klaipèdos miestų istoriniuose centruose

Table 2. Dispersion of functions in historic city centres of Kaunas and Klaipeda

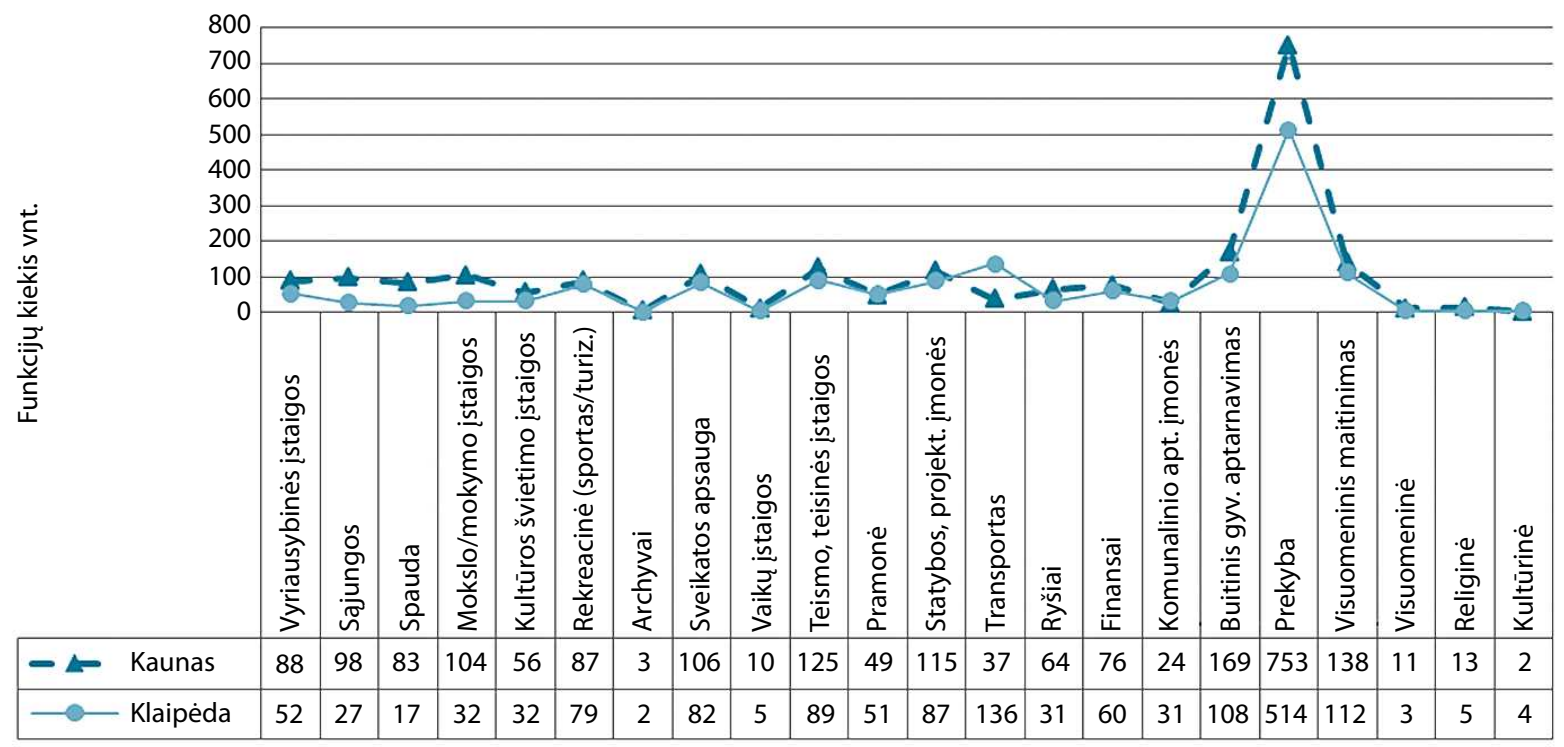


cijas. Kauno miesto istorinès dalies dominuojančios funkcijos yra: prekybinè (753), buitinio gyventojų aptarnavimo (169), visuomeninio maitinimo (138), teisinès îstaigos (125), statybos ir projektavimo (115), mokslo ir švietimo įstaigos (104) bei vyriausybinès ịstaigos (88). Visos šios funkcijos įsikūrusios prestižiniuose ir patraukliuose centriniuose miesto kvartaluose, atlieka atstumiančiu funkciju vaidmenị funkcine prasme. Funkcijas pagal ju veiklos sritis ir pobūdi galima suskirstyti i du pagrindinius tipus, tai atstumiančios funkcijos (neigiamos), kurios atsiradusios tam tikroje teritorijoje išstumia gretimas gyvavusias funkcijas, ir pritraukiančias funkcijas (teigiamas), kurios ne tik funkcionuodamos generuoja pèsčiųjų ir transporto srautus, bet taip pat pritraukia gretimas funkcijas. Klaipėdos miesto istorinès dalies funkciju analizèje taip pat pastebimas: prekybos (514), išskirtinai transporto (136), visuomeninio maitinimo (112), statybos ir projektavimo imonių (87), teisinių (89) funkcijų dominavimas. Šias tyrinètas istorinio branduolio Kauno ir
Klaipèdos funkcijas dar galima grupuoti pagal funkcijos koreliaciją su gyvenamąja funkcija (3 lentelè).

Analizuojant Kauno istorinès dalies funkcijas pastebèta, kad jos kinta ne tik nuo ją veikiančių socialinių, ekonominių, technologinių veiksnių, bet jos kaitai taip pat ittaką daro funkcijų dydis (mastelis) ir lokacija (vieta). Mažejjant gyventojų skaičiui istorinejje miestų dalyje natūraliai kyla klausimas, kas tai nulèmè. Puikus pavyzdys - Laisvės alëja Kaune (pagrindinis miesto simbolis ir pasididžiavimas) yra ištuštejusi. Funkcijų koreliacijos lenteleje (3 lentelè) matyti ryškus vyriausybès funkcijų, teismo ịstaigų, visuomeninių ir vyriausybès įstaigų funkcijų dominavimas, kurios Kauno istorinị branduolį paverčia administraciniu centru. Atstumiančios (neigiamos) funkcijos dažniausiai nèra pritaikytos funkcionuoti senamiesčio ar centrinèse miesto dalyse, nes jos ne tik negeneruoja pèsčiujų srautų, bet ir sukelia automobilių statymo problemų. Dažnai šios funkcijos, pradetos taikyti pastatuose, keičia pačių pastatų planinę ir fizinę struktūrą (3 pav.),

3 lentelè. Kauno ir Klaipėdos funkciju ir gyvenamosios funkcijos koreliacija (vnt / \%)

Table 3. Correlation between functions of Kaunas and Klaipeda and their residential function

\begin{tabular}{|c|c|c|c|c|}
\hline \multirow{2}{*}{$\begin{array}{l}\text { Funkcijos, kurios koreliuojasi su gyvenamąja funkcija } \\
\text { Mokslo, mokymo }\end{array}$} & \multicolumn{2}{|c|}{ Kaunas } & \multicolumn{2}{|c|}{ Klaipèda } \\
\hline & 104 & $4,7 \%$ & 32 & $2,1 \%$ \\
\hline Švietimo & 56 & $2,5 \%$ & 32 & $2,1 \%$ \\
\hline Rekreacinè (sportas, turizmas) & 87 & $3,9 \%$ & 79 & $5,1 \%$ \\
\hline Sveikatos apsaugos & 106 & $4,8 \%$ & 82 & $5,3 \%$ \\
\hline Vaikų istaigos & 10 & $0,5 \%$ & 5 & $0,3 \%$ \\
\hline Komunalinio aptarnavimo & 24 & $1,1 \%$ & 31 & $2,0 \%$ \\
\hline Buitinio gyventoju aptarnavimo & 169 & $7,6 \%$ & 108 & $6,9 \%$ \\
\hline Prekybos & 753 & $34,1 \%$ & 514 & $33,0 \%$ \\
\hline Visuomeninio maitinimo & 138 & $6,2 \%$ & 112 & $7,2 \%$ \\
\hline Religinè & 13 & $0,6 \%$ & 5 & $0,3 \%$ \\
\hline Kultūrinè & 2 & $0,1 \%$ & 4 & $0,3 \%$ \\
\hline Funkcijos, kurios nesikoreliuoja su gyvenamąja funkcija & \multicolumn{2}{|c|}{ Kaunas } & \multicolumn{2}{|c|}{ Klaipèda } \\
\hline Vyriausybinè & 88 & $4,0 \%$ & 52 & $3,3 \%$ \\
\hline Sąjungos & 98 & $4,4 \%$ & 27 & $1,7 \%$ \\
\hline Spauda & 83 & $3,8 \%$ & 17 & $1,1 \%$ \\
\hline Archyvai & 3 & $0,1 \%$ & 2 & $0,1 \%$ \\
\hline Teismo, teisinès & 125 & $5,7 \%$ & 89 & $5,7 \%$ \\
\hline Pramonès & 49 & $2,2 \%$ & 51 & $3,3 \%$ \\
\hline Statybos, proj. organizacijos & 115 & $5,2 \%$ & 87 & $5,6 \%$ \\
\hline Transporto & 37 & $1,7 \%$ & 136 & $8,7 \%$ \\
\hline Ryšiai & 64 & $2,9 \%$ & 31 & $2,0 \%$ \\
\hline Finansinè & 76 & $3,4 \%$ & 60 & $3,8 \%$ \\
\hline Visuomeninè & 138 & $0,5 \%$ & 112 & $0,2 \%$ \\
\hline
\end{tabular}






3 pav. Pakitusi planinè ir fizinè Kauno ir Klaipèdos senamiesčio pastatų struktūra

Fig. 3. The transformed panned and physical structure of buildings in old towns of Kaunas and Klaipeda

nes pastatai nèra pritaikyti šioms administracinèms ir finansinèms funkcijoms.

Vienas iš svarbiausių funkcijų egzistavimo ir kaitos elementų yra pesčiųjų ir transporto srautai (Kasanko et al. 2005). Atstumiančios funkcijos generuoja žmonių ir transporto srautus per darbo savaitę ir darbo valandomis, tačiau savaitgali gyventojams ir turistams tai nèra traukos centrai. Pagrindiniai turistų traukos centrai yra tie, kurie atlieka kultūrinę, religinę, visuomeninio maitinimo ir prekybos funkcijas. Vienintelè turistų traukos - prekybinè funkcija - išsiskiria Kauno istorinejje aplinkoje. Pritraukiančios (teigiamos) funkcijos - komercinès, visuomeninio maitinimo, paslaugų - veikia kaip traukos taškai. Šios funkcijos koreliuoja su gyvenamąja funkcija ir generuoja pèsčiųjų ir transporto srautus.

Pavyzdys yra prabangių prekių parduotuvès, kuriose parduodami drabužiai, batai ar laikrodžiai. Tačiau šios monofunkcijos nesukuria pastovių pèsčiujų srautų. I vieną aspektą orientuotoms specializuotoms funk- cijoms išsilaikyti yra sunku dèl gausią funkcijų įvairovę turinčio naujojo PC „Akropolis“ ir naujai pastatytos Kauno arenos (4 pav.).

Keli pagrindiniai funkcijų slinktį nulèmę veiksniai - tai funkcijų (paslaugų) gausa po uždaru stogu, darbo laiko grafikas ir laisvalaikio pramogu gausa, nemokamos automobilių stovejjimo aikštelès, kurių irengimas yra aktuali tema istoriniuose miesto branduoliuose.

Todèl Laisvès alèjos vidutinio ir didelio mastelio funkcijos mutuoja (keičiasi) į kompleksines ir sudètines funkcijas, eliminuodamos (nukonkuruodamos) smulkiąsias. Taip buvusių smulkių funkcijų vietas užima naujos lankstesnès funkcijos, inicijuotos savaiminio mutacijos proceso.

Panaši funkcijų slinktis ir sklaida pastebèta Klaipedos istoriniame branduolyje (5 pav.). Klaipedos istoriniame branduolyje telkiasi prabangių prekių parduotuvès, kurios dèl aukštų nuomos ir nekilnojamojo turto kainų išsidèsto prie reikšmingų (centinių) gatvių, 


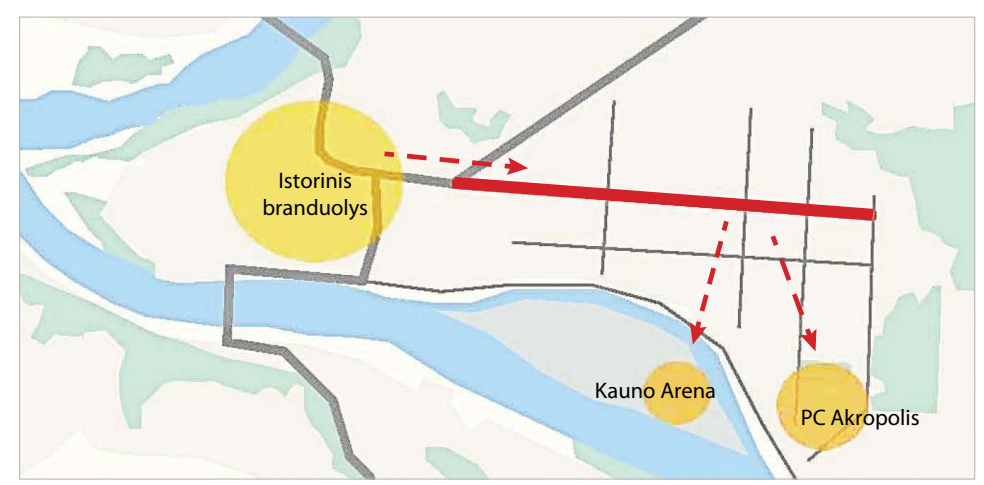

4 pav. Kauno istorinio branduolio funkcijų slinktis

Fig. 4. Functional displacement of the historic core of Kaunas

aikščiu, t. y. geriausiose vietose. Per tyrimą pastebèta, kad komercinès funkcijos išsidèsto ne tik pastatuose, esančiuose pagrindinèse gatvèse, bet taip pat ir rekonstruotuose pastatuose, kurie anksčiau buvo naudojami sandeliavimo ar kitoms reikmèms. Taip pat pastebèta, kad pastatuose buvusios didesnès patalpos transformuojamos ị mažesnes pritaikant komercinei funkcijai pagal esamą rinkos poreikį.

Taigi funkcijų sklaidą miesto istoriniame branduolyje lemia prestižas, mada ir nekilnojamo turto kaina, kurie prilygsta Europos didmiesčiams. Monofunkciškumą netiesiogiai diktuoja ir didieji prekybos centrai gyvenamųjų rajonų prieigose. Be to, jie lengviau pasiekiami ir mažina gyventojų ir turistų srautus ị istorinị centrą. Klaipedos miesto istorinès dalies analizèje aiškiai išsiskiria dominuojanti prekybos, transporto, statybos ir projektavimo bei visuomeninio maitinimo funkcijos. Šių funkcijų dominavimas lengvai paaiškinamas dèl Klaipedos uostamiesčio dominuojančio krovinių ir turistinio transporto. Tačiau Klaipedos ir Kauno miestų istorinio branduolio problematika yra panaši. Istorinio branduolio funkcijas nukonkuruoja naujai įsikūrę prekybos centrai ir pramogų arenos. Žmonių mobilumo ir funkcijų sklaidos priklausomybę lemianti funkcijų lokacija ir jų mastelis yra verčiami prisitaikyti prie kintančių miesto gyventojų poreikių, tuo skatindami mutacijų procesus.

Boschma ir Lombooy (2002) teigia, kad „besimokančio miesto" formavimąsi galima taikyti ir apibendrinant miestą veikiančius veiksnius. Jie teigia, kad pagrindiniai šiuolaikinio miesto formavimosi veiksniai yra sklandžiai veikiantys tinklai ir nuolatiniai kaitos procesai. Kadangi miestų vystymas - nuolatinis funkcinès ir fizinès kaitos pagrindas, jis daugiausia remiasi neapčiuopiamais ir per ilgą laiką susiformavusiais veiksniais: susiklosčiusia politine tvarka, visuomenès pripažistamomis normomis, technologijomis, infrastruktūros ir kultūros išsivystymu ir t. t.

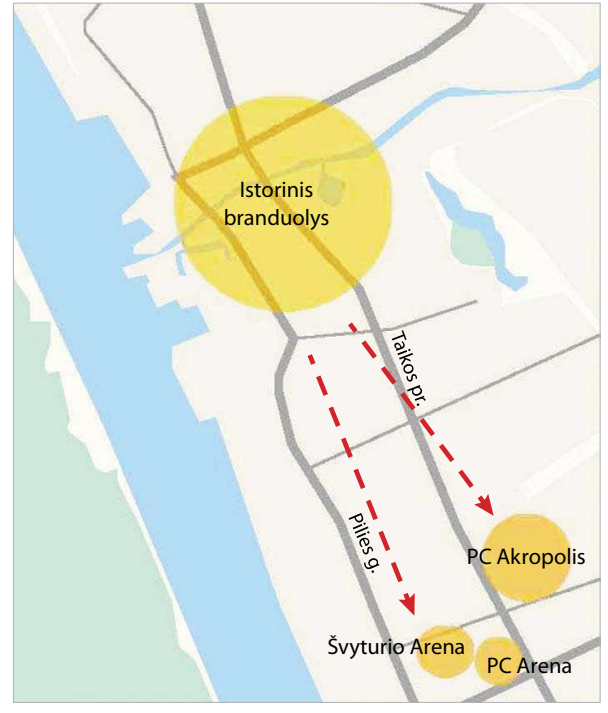

5 pav. Klaipedos istorinio branduolio funkciju slinktis

Fig. 5. Functional displacement of the historic core of Klaipeda

\section{Išvados}

Veikiamas rinkos ekonomikos šiuolaikinių miestų vystymasis yra neatsiejamas nuo socialinių veiksnių, globalizacijos, naujųjų technologijų ir daugelio kitų kompleksinių veiksnių. Tiesioginè vertikali ir horizontali minètų veiksnių sąveika per tam tikrą laiką keičia fizinę ir funkcinę miestų istorinių centrų aplinką ir struktūrą. Istoriniuose branduoliuose saugomos fizinès struktūros, tačiau nèra kreipiamas dèmesys išsaugoti jų funkcinę struktūrą. Todèl vertètų kontroliuoti ne tik žemès kainą istoriniuose branduoliuose, bet ir funkcijų pusiausvyrą, sudarant tinkamą proporciją tarp gyventojų ir funkcijų, išlaikant miesto vystymo ekonominę ir socialinę pusiausvyrą.

Atliekant tyrimą Kauno ir Klaipedos miestų pavyzdžiu nustatyti veiksniai savaime negarantuoja inovacijų proceso plettros, nes miestai yra itin individualūs ir heterogeniški. Todèl miestą suprantant kaip planavimo sistemos, gyventojų poreikių ir kitų veiksnių santalkos objektą (gyvą organizmą), būtina atsižvelgti i ’minkštuosius" veiksnius ir kitus sąveikos aspektus.

Radikaliai keičiantis socialiniams santykiams, auga istorinių centrų svarba. Centrinėse miestų ir istorinių branduolių dalyse teikiamas pranašumas pèsčiųjų eismui, tačiau sumažinus visuomeninio transporto srautą išaugo lengvụjų automobilių naudojimas, kuris didina funkcijų sklaidą, jas decentralizuoja. Todèl susikūrę prekybos centrai nukonkuruoja istorinių miestų branduolius ir perima jų funkcijas. Tad iškyla grèsmè istorinio branduolio išnykimui. 
Istorinių branduolių gyventojų skaičiaus mažèjimą ir jų transformavimąsi į administracinius centrus nusako gyventojų aptarnavimo paslaugų mažejimas, vis didesnis sezoniškumas ir pritaikymas masinio turizmo reikmèms, rezervato ir muziejaus požymiai, trumpejjantis patrauklios veiklos laikotarpis paros cikle. Tikslingas ir apskaičiuotas koreliuojančių funkciju pritaikymas istorinių branduoliu dalyse veiktų kaip traukos šaltiniai, kurie grąžintu žmones ir gyventojus i istorinius centrus.

Globalizacijos ir technologijų vystymosi sparta naikina barjerus pasaulinei žmonių migracijai. Dèl to formuojasi naujos urbanistinès struktūros su joms būdingais gyvenamaisiais modeliais (kvartalais), kuriuose gyvenama, dirbama. Gyvenamosios aplinkos funkcinè kokybè priklauso nuo socialinių paslaugu egzistavimo, prieinamumo ir jų ivairovès. Formali planavimo logika sako, kad funkcinès kokybès rodikliai turètų būti maksimalūs, o jų teritorinè sklaida tolygi.

\section{Literatūra}

Burdett, R.; Sudjic, D. 2008. The Endless City. London: Phaidon Press Ltd.

Boschma, R. A.; Labmooy, J. G. 2002. Knowledge, market structure, and ec onomic coordination:dynamics of industrial districts, Growth and Change 33: 291-311. doi:10.1111/1468-2257.00192

Castells, M. 2005. The rise of the network society. Oxford: Blackwell publishing, Ltd.

Galinie, H.; Rodier, X.; Saligny, L. 2004. Entités fonctionnelles, Entity spatiale et dynamique urbaine dans la Longue Durée [interaktyvus], [žiūrèta 2009 m. lapkričio 08 d.]. Prieiga per internetą: <http://histoiremesure.revues.org/ index761.html>.

Geyer, H. S. 2001. Development planning transition in South Africa, in H. C.Marais; Y. Methien; N. S. Jansen van Rensburg; M. P. Maaga; G. F. de Wet; C. J. Coetzee (Eds.). Sustainabl social development: critical dimentions. Pretoria: Network Publishers, 143-152.

Jucevičius, G. 2007. Inovatyvūs miestai ir regionai: monografija. Kaunas: Technologija.

Juškevičius, P.; Valeika, V. 2007. Lietuvos miestu sistemu raida. Vilnius: Baltijos kopija.

Kasanko, M., et al. 2005. Are Europe ties becoming dispearsed? A comparative anglysis of 15 European urban areas, Landscape and Urban Planning 77: 111-130. doi:10.1016/j.landurbplan.2005.02.003

Korcelli-Olejniczak, E. 2007. Metropolitan Functions as a Research Question: Definitions and Identifications in the ESPON and Alternative Approaches. GaWC Research Bulletin 248 [interaktyvus], [žiūrèta $2011 \mathrm{~m}$. sausio 26 d.]. Prieiga per nternetą: <http://www.lboro.ac.uk/gawc/rb/ rb248.html>.

Marshall, J. U. 1989. The Structure of Urban Systems. Toronto: University of Toronto Press.

Mitchell, W. J. 2002. E-topija. Vilnius: Pasviręs pasaulis.

Mozūriūnaitè, S. 2010. Urbanistinių funkcijų kaitą lemiantys veiksniai ir jų tyrimo klausimai, Urbanistika ir archi- tektūra [Town Planning and Architecture] 34(2): 90-97. doi:10.3846/tpa.2010.08

Mumford, L. 1953. La cultura delle citta. Editzioni di Comunita. Milano.

Rogers, R.; Rogers, R. G.; Power, A. 2000. Cities for a Small Country. London: Faber and Faber.

Stenger, M. B. 2008. Globalizacija: labai trumpas įvadas. Vilnis: Aušra.

William, J. M. 2002. E-topia: "Urban life Jim - but not as we know it". London: The MIT press.

\section{THE ANALYSIS OF FUNCTIONAL MUTATION AND ITS INFLUENCE ON THE HISTORIC PARTS OF KAUNAS AND KLAIPĖDA CITIES}

\section{S. Mozūriūnaitè}

Abstract. The article discusses the features of urban spread in Lithuanian cities. It provides a detailed overview of the social, economic, physical, technological and global factors as well as their mutual interaction considering a time aspect. The article deals with the factors and reasons that caused the functional loss of the central parts of Kaunas and Klaipeda cities. Besides, it analyses the change in the urban function dispersion and the factors affecting and determining urban mutations. This article discusses the consequences of urban functions, their factors and trends. The goal of the article is to discuss the factors and implications or urban functional mutations in an urban historic environment.

Keywords: mutations, factors, transformations, decline of functions, dispersion, functional mutations, urban transformation, factor model.

\section{SKIRMANTE் MOZŪRIUNAITE்}

PhD student, assistant, Dept of Urban Design, Vilnius Gediminas Technical University (VGTU), Pylimo g. 26/Traku g. 1, 01132 Vilnius, Lithuania.

E-mail smozuriunaite@gmail.com

Projects: author or co-author of master plans and detailed plans, individual housing design. Research interests: urbanism, urban functional mutations, urban morphology. 